\title{
SEEKING THE CAUSES OF URBAN RUINATION: AN EMPIRICAL RESEARCH IN FOUR PORTUGUESE CITIES
}

\author{
Eduardo Brito-Henriques (iD • David Cruz \\ Universidade de Lisboa \\ Centre for Geographical Studies \\ Institute of Geography and Spatial Planning \\ IGOT, Rua Branca Edmée Marques, 1600-276 Lisbon: Portugal \\ e-mails: eduardo@campus.ul.pt・fabio.d.cruz@campus.ul.pt
}

\begin{abstract}
Urban ruination is an understudied feature in the life of cities. This article discusses its causes. Based on the study of four shrinking Portuguese cities (Lisbon, Barreiro, Guimarães and Vizela), and using Multiple Linear Regression Analysis as the statistical method, the structure of relationships among ruins, economic change, demographic change, social geography and the characteristics of buildings are discussed. Although the study concludes that ruination is a highly contingent phenomenon, the results show that of all the structural factors, demographic ageing and the obsolescence of buildings (poor housing conditions) are the key causes of ruination in the four cities under study. Links between ruination and socio-spatial processes have also been identified.
\end{abstract}

\section{Key words}

ruins - ruination $\cdot$ urban abandonment - vacant properties $・$ shrinking cities - Portugal

\section{Introduction}

The first image that probably comes to mind when one hears about urban ruins is that of cities ravaged by cataclysms and wars. Collapsed buildings, heaps of debris and devastation scar the landscape in the aftermath of earthquakes, cyclones, explosions and bombings. Not all ruins, however, are the result of such events. In addition to 'fast ruins', borne out of the aforementioned type of violent eruptions, there are also 'slow ruins' which are silently produced over time, resulting from incremental destruction processes (DeSilvey \& Edensor 2013: 466). This latter type is the most common and may be observed in all cities, albeit to varying degrees, and also to different extents in neighbourhoods within the same city.

For a long time, concepts such as urban decay and urban crisis have been used in urban geography to describe trends and processes related to the decadence of cities. These concepts, however, refer more to the 
economic and demographic vitality of the urban fabric than to their physical materiality. Moreover, they had implicit a metaphorical idea of life cycle in the light of which phases of apogee and phases of decline succeed in cities, and periods of growth and expansion (supposedly positive or beneficial) oppose to periods of regression and contraction (supposedly negative or harmful). In recent years, this duality began to be called in question (Hollander 2010; Woodward 2012; Hospers 2014; Schlappa 2016). On the other hand, everywhere we look in the social sciences, "we are witnessing scattered but insistent demands for [...] new ways of thinking about matter and processes of materialization" (Coole \& Frost 2010: 2). This 'materialist turn' explains that a renewed attention is being given to the built environment and the material culture of cities by the urban studies. As such, ruination has appeared as a more appropriate term to describe the full complex reality that is the material transformation of the city related to abandonment, vacancy and shrinkage (Pétursdóttir 2012; DeSilvey \& Edensor 2013).

Indisputable though it is that ruination goes hand in hand with stories of abandonment and sidelining, the specific reasons that give rise to such abandonment, and consequently ruination, appear to be ambiguous. Some theoretical interpretations stress the structural causes of an economic nature, related to accumulation logics and global capital strategies (Edensor 2005; Martin 2014; Apel 2015), while others prefer to highlight societal reasons, related to shifts in demography, lifestyles or even resulting from political options (Hoyt 1939; Florentin et al. 2009; Rieniets 2009). Others even place emphasis on the materiality of objects and places, and on the tension brought about by the speed of time on this materiality, thus stressing the obsolescence of the built environment (GonzálezRuibal 2008; Brito-Henriques 2017).

In the last few years, a considerable effort was dedicated to solving this controversy and understanding more clearly the causes and factors of urban dereliction. The body of criticism contesting 'macro-theoretical conceptualizations' and defending "reflections on the [...] 'real-world processes' that occur in [... actual] cities and are detected by empirical research" (Haase et al. 2014: 1524) has been seriously taken into consideration in this recent research. Thus, several studies were published with the objective of describing and explaining the spatial distribution of vacant lands and abandoned structures in the cities, using GIS, multivariate statistical analysis and predictive modelling (Hollander 2011; Silverman et al. 2012; Deng \& Ma 2015; Newman et al.2016; Newman \& Kim 2017; Newman et al. 2018). However, almost all of these studies have been conducted in US cities, so one may wonder whether the conclusions drawn in them are applicable for cities in other regions.

This article follows the same type of objectives and methodology applied to four Southwestern European cities: Lisbon and Barreiro in the centre-south of Portugal, and Guimarães and Vizela in the northwest of Portugal. Reviewing the literature, one perceives that opinions are divided on the causes and the determinant factors for urban abandonment and ruination. Four different types of factors usually appear related to this, namely: economic changes, especially deindustrialization and crisis; demographic changes, such as ageing and suburbanization; social marginalization, namely poverty and racialization; and the characteristics of the built environment and housing market. In this article, we will test these various hypotheses, by investigating which of these factors best explain the distribution of derelict and ruined structures in the four cities studied.

The article is structured as follows. Its first section seeks to theoretically frame the issue in question, to review the main explanatory ruination models and to present the hypotheses that will be tested. This is followed by a description of the data and methodology, which includes both a detailed presentation of the variables under study and an introduction to the abovementioned four cities. The section immediately after focuses on the 
presentation and discussion of results. The article ends with a conclusion in which the main inferences to be drawn from the present study are summarized.

\section{Theoretical background}

In urban studies, abandonment and ruination of the built environment have been indirectly addressed with regard to issues such as neighbourhood changes, the urban life cycle and, more recently, shrinking cities. Among these varied perspectives, different explanatory hypotheses and interpretations of ruination have been advanced.

One of the most classic and widespread explanations associates abandonment of the built environment and urban ruination with the growth of cities. The first theorizations on urban ruination, in these terms, emerged with the studies on urban development and neighbourhood change produced by the Chicago School in the 1920s and 30s. According to the urban social-ecological perspective, ruination was part of the 'natural evolution' of the city and a direct consequence of suburbanization. As activities and more prosperous families expanded, migrated and colonized new places, they would leave derelict areas in their trail that were later invaded by activities and social groups of a lower category (Burguess 1929). In this invasionabandonment-succession process, which corresponded to urban growth, a physically and socially 'deteriorated area' would form in the inner rings of the city according to this theory.

The implied relationship between suburbanization and ruination, initially advanced in the social-ecological models of the Chicago School, has been reiterated and reinforced by new arguments over the last decades with the discussion on urban sprawl. The idea of a peri-urban expansion accompanied by a de-densification of the consolidated city is intrinsic to the urban sprawl concept (Couch et al. 2007). Nowadays, it is practically taken for granted that the dispersion of populations and activities as a result of urban sprawl leads to the decline of central urban areas
(Beauregard 2012), and some authors go as far as to hold suburbanization largely responsible for urban shrinkage (Audirac 2009; Florentin et al. 2009; Bontje \& Musterd 2012). However, the data gathered so far do not allow inferring that urban sprawl is a cause of built dereliction. In the US cities, it has been proved that "cities with higher elasticity were likely to have more vacant land [...] while structural abandonment seems to more heavily influenced by population decrease" (Newman et al. 2018: 427).

The link between abandonment and ruination and social marginalization and exclusion has also been handed down by the Chicago School tradition. By characterizing the 'deterioration area' around the city centre as a ring of vice and disorder, Burguess (1929) was one of the first to establish an association between ruination and social problems. The controversial broken windows theory later came to posit that property abandonment and the decay of the built environment triggered incivility and delinquency, and vice versa, in a vicious circle (Kelling \& Wilson 1982). The racial issue was brought to the debate by Hoyt (1939), who observed that in Richmond, Virginia, neighbourhoods with residences in a poor state of repair had higher proportions of black people. Since then, the association between abandoned and derelict properties and the presence of ethnic minorities has been corroborated by several research studies in North-American cities (Hollander 2011; Silverman et al. 2012; Hackworth 2016). The literature also points to a higher number of abandoned properties in the census tracts where higher poverty rates are found (Silverman et al. 2012; Deng \& Ma 2015).

Other studies have preferred to highlight the economic factors over the societal features of ruination. The shrinking cities debate over recent years has brought these types of factors to the limelight, associating the abandonment and ruin of the built environment with transitions between economic cycles, economic restructuring and crisis (Martinez-Fernandez et al. 2012; Wiechmann 
\& Pallagst 2012). Unemployment, caused by the exhaustion of a resource or by the end of an activity, is described as a direct cause of abandonment outbreaks in mining cities, for instance (Oswalt \& Rieniets 2006). Deindustrialization has repeatedly been advanced as a major cause of divestment in the built environment and the proliferation of empty buildings and ruins in the cities of the old industrialized countries (Bluestone \& Harrisson 1982; Edensor 2005; Mah 2012). Some studies suggest that the presence of abandoned and empty properties is less perceptible in the spaces of the 'new urban regime', where institutions and social groups linked to the knowledge economy and information society reign (Silverman et al. 2012). The effects of cyclic capitalism crises in the production of ruins are also documented in studies showing how the dot-com crash of the turn of the century (Frey 2005) and, more recently, the subprime mortgage crash and global financial crisis of 2008 left behind high-rises of empty offices and created 'ghost estates' and 'new ruins' made up of unfinished constructions (Hollander 2011; Pálsson 2012; Kitchin et al. 2014). Nevertheless, the role of economic crisis as a major cause of urban ruination is not corroborated throughout the literature. Although crisis may explain outbreaks of ruins in some places, structural links between unemployment variations and the presence of derelict buildings have not been found in the US cities (Pagano \& Bowman 2000; Newman et al. 2018).

In the same vein, long-term demographic changes may also explain urban shrinkage and, hence, urban abandonment and ruination. Low fertility rates and ageing are generating negative natural growth in broad regions of the Global North, with a loss of population and the generation of surplus spaces in these territories (Wiechmann 2008; Rieniets 2009).

A common feature among all the aforementioned explanations is that they attribute the causes of building abandonment and ruination to external variables that are not directly dependent on the characteristics of the built environment and structures. However, it is plausible that factors related to the housing market and the characteristics of the buildings themselves also have a bearing on abandonment and divestment. Despite contradictory conclusions, the type of proprietor is a seemingly relevant variable: while some studies argue that the social housing sector is more efficient than the private sector with regard to maintaining housing stock in use (Couch \& Cocks 2013), others claim that higher rates of residential vacancy are found in census tracts with government subsidized rental housing (Silverman et al. 2012). Some studies also point to the age of the buildings as a relevant factor when noting that neighbourhoods with older residences present a higher proportion of abandoned properties (Silverman et al. 2012; Deng \& Ma 2015). The quality and comfort of the residences should also be taken into consideration, as in the specific case of Liverpool, United Kingdom, vacant residences were observed to be geographically concentrated in certain inner urban areas of poor quality private housing (Couch \& Cocks 2013).

\section{Data and methodology Choice of variables}

The variables considered for this study are set out in Table 1. Given the issue at hand, the presence and density of ruins is the dependent variable. A ruin should be interpreted as each and every abandoned human construction with such extensive need of repair that it is unable to effectively function for its intended purposes. Therefore, all constructions fall under this category - residential and nonresidential buildings, including infrastructures - that are partially destroyed and vacant (i.e., without regular conventional usage), as well as boarded up buildings. Aborted constructions are also regarded as ruins, i.e. buildings whose construction work has been suspended, leaving them unfinished.

In order to relate to and explain ruination, ten independent variables were considered. These variables reflect the four factors 
or dimensions of analysis that are established in the literature as being most relevant to the issue at hand: (I) demographic changes; (II) economic changes; (III) social marginalization; (IV) and the characteristics of buildings and housing market.

The demographic variables refer more directly to the theories that relate ruination to ageing and suburbanization. Our aim was to test whether the population loss and demographic ageing are reflected in the presence and density of ruins, as suggested by these theories.

Inclusion of the employment and economic activities variables was to grasp the importance of economic change and crisis in ruination. Variation of the resident population employed in the secondary sector was used as a proxy measure of deindustrialization, while the unemployment rate was used as a proxy of crisis. If the importance of these factors in the triggering of ruination processes is confirmed, active population loss in the secondary sector and high unemployment rates will be reflected in a greater presence and density of ruins.

A further three variables related to social structure were also considered. The proportion of inhabitants with higher education was selected to test the hypothesis that the spaces associated with the 'new urban regime' of the knowledge economy are less prone to the abandonment and ruination of the built environment, as Silverman et al. (2012) claimed. The other two variables were chosen to measure the influence of social marginalization on urban ruination.Thus, the percentage of income support recipients was used as a proxy measure of poverty, while the percentage of foreign inhabitants from non-European countries was used to evaluate racialization (Portuguese law strictly prohibits the collection of direct data on the skin colour of people and ethnic origin).

Table 1. Dependent variable and independent variables identified as potential drivers and factors of ruination

\begin{tabular}{|c|c|c|c|}
\hline $\begin{array}{l}\text { Dimension } \\
\text { of analysis }\end{array}$ & Variable & Unit & $\begin{array}{l}\text { Data } \\
\text { source }\end{array}$ \\
\hline \multicolumn{4}{|c|}{ Dependent variable } \\
\hline Ruination & density of ruins & number $/ \mathrm{km}^{2}$ & $\begin{array}{l}\text { digitalization based } \\
\text { on aerial imagery }\end{array}$ \\
\hline \multicolumn{4}{|c|}{ Independent variables } \\
\hline Demography & $\begin{array}{l}\text { population growth 2001-11 } \\
\text { ageing index }\end{array}$ & $\begin{array}{l}\% \\
\%\end{array}$ & $\begin{array}{c}\text { census 2001, census } 2011 \\
\text { census } 2011\end{array}$ \\
\hline $\begin{array}{l}\text { Employment } \\
\text { and economy }\end{array}$ & $\begin{array}{l}\text { variation of resident population em- } \\
\text { ployed in secondary sector 2001-11 } \\
\text { unemployment rate }\end{array}$ & $\%$ & $\begin{array}{c}\text { census 2001, census } 2011 \\
\text { census } 2011\end{array}$ \\
\hline Social structure & $\begin{array}{l}\text { income support recipients } \\
\text { foreign residents from non-European } \\
\text { countries }\end{array}$ & $\begin{array}{l}\% \\
\%\end{array}$ & $\begin{array}{l}\text { census } 2011 \\
\text { census } 2011\end{array}$ \\
\hline & $\begin{array}{l}\text { residents with higher education (over } \\
25 \text { years) }\end{array}$ & $\%$ & census 2011 \\
\hline $\begin{array}{l}\text { Buildings and } \\
\text { housing market }\end{array}$ & $\begin{array}{l}\text { residences in buildings constructed } \\
\text { prior to } 1946\end{array}$ & $\%$ & census 2011 \\
\hline & residences without bathroom facilities & $\%$ & census 2011 \\
\hline & $\begin{array}{l}\text { public housing (State, public institution } \\
\text { and municipality-owned properties) }\end{array}$ & $\%$ & census 2011 \\
\hline
\end{tabular}


Finally, three variables related to the characteristics of the built environment and the housing market were also selected. Through their inclusion in the model, we wanted to test whether the agedness of buildings, the poor conditions of habitability, and the type of owner influence presence of ruins and derelict structures as investigations carried out in other countries apparently suggest. Thus, in addition to the agedness of buildings, measured by the percentage of constructions prior to 1946, the percentage of housing without bathroom facilities (as an indicator of discomfort and poor quality housing) and the percentage of public housing sector (State, public institution and municipality-owned properties) were also taken as independent variables.

\section{Sources, data collection and analysis method}

All the independent variables corresponded to secondary data and were collected from official censuses. The data was analysed on the basis of a spatial breakdown by freguesia ${ }^{1}$. Whenever these freguesias were observed to be intercepted by the urban perimeter, thus being both partially within and beyond the boundaries of the cities, data was compiled by census blocks, taking the sum of the part within the urban perimeter into consideration.

To date, the majority of studies on urban abandonment and ruination have used secondary data or indirect methods to account for abandoned spaces, such as direct questioning technicians in the housing and urbanism services of cities (Accordino \& Johnson 2000), figures inferred from information on vacant residences in housing censuses (Hollander 2011), and information provided by post offices on properties without a postal

1 In Portugal, freguesia is the smallest administrative division, corresponding to the sub-division of a municipality (municipalities are referred to as concelhos). These freguesias originate from parochial jurisdictions and are equivalent to wards, in an urban context. service or with uncollected correspondence (Silverman et al. 2012). However, these are precisely the first studies to acknowledge the limitations of the sources used by taking the control over the criteria and accuracy of the figure calculations away from the researchers (Pagano \& Bowman 2000).

To get around this difficulty, in the present study the dependent variable was obtained by our own collection. A full inventory of the ruins in the cities under study was conducted by remote sensing, based on the combined use of vertical and horizontal photographs (see Brito-Henriques et al. 2018). For the cities of Barreiro and Lisbon, the sources used were high resolution digital orthophotos $(0.10 \mathrm{~m})$ obtained from a flight in 2014, which covered the coastal municipalities of Mainland Portugal, and accessible through the Web Map Service (WMS) on the Directorate-General of Territorial Development website. For the cities of Guimarães and Vizela, orthophotos with a spatial resolution of $0.30 \mathrm{~m}$, produced in 2015, and provided by the local authorities were used. These sources made it possible to conduct a full scan of the cities, pinpointing potential ruins on the basis of the state of the rooftops and appearance of gardens and patios. This initial identification was later confirmed and assisted by the viewing of horizontal images by Google Street View, available through the Google Earth application, which provides ground level photographic records with a panoramic coverage of $360^{\circ}$ and a time-lapse option. Whenever a street view was not available through this web resource, or its viewing was not totally conclusive, field work was then put into action.

After collecting and organizing the information, the data was imported into SPSS for multiple linear regression analysis. The stepwise method was used to insert the variables into the model, as this appeared to be the most suitable method for exploring and comparing the relative contribution of each of the predictors in explaining the variance. The application assumptions of the multiple linear regression were tested and the suitability of the method to the nature of the data was 
confirmed, as will be shown in more detail further on in this paper.

\section{Study areas}

The data was collected from four Portuguese cities, which are illustrative of different urban situations in different regional contexts: Barreiro, Guimarães, Lisbon and Vizela (Fig. 1). They all share the common fact of having lost population between the last two censuses (from 2001 to 2011). They are, however, different sized cities. On one hand, there is Lisbon, the Portuguese capital, with 547,733 inhabitants in an area of around $85 \mathrm{~km}^{2}$, and on the other, Vizela, a small provincial city with 10,633 inhabitants in an area of $6.8 \mathrm{~km}^{2}$ (figures reported in 2011). In the middle of these extremes, there is Guimarães, a typically medium-sized city, according to Portuguese standards, with 47,588 inhabitants in an area of $23.5 \mathrm{~km}^{2}$, and Barreiro, with 37,506 inhabitants concentrated in an urban area comparable to that of Vizela (also data from the last census).

Lisbon and Barreiro belong to the same region. They are both located on the banks of the Tagus estuary, on heavily urbanised territory, which corresponds to the country's main urban conurbation, home to 2.8 million inhabitants and to over $40 \%$ of national enterprise production. Lisbon is the centre of this broad metropolitan area and Barreiro a former suburb of its rust belt. Despite being the main political and economic decisionmaking centre of the country, Lisbon has seen a demographic regression over the past three decades. The effect of suburbanization, associated with smaller sized families and ageing, gave rise to a population loss of $17.4 \%$ in this city between 1991 and 2011 (approximately 115,660 inhabitants), becoming one of the most shrunken European capitals in this period. At the same time, Lisbon became deindustrialized: over the last decade, a variation of $-40.7 \%$ has been observed in the number of residents employed in the secondary sector, which had dropped to three quarters after 1981. In 2011, $15.5 \%$ of residences in the city were vacant according to the housing census.

Barreiro is a paradigmatic example of an old industrial suburb in crisis, with a trail of brownfields and contaminated soils. In a Portuguese context, it is probably the closest case to the 'company town' model. The city saw extraordinary progress after establishment of the CUF industrial complex in 1908. The CUF group was the largest Portuguese economic group for decades. Its headquarters and the group's main industrial park linked to the chemical (acids, fertilizers, oils, soaps, etc.), textile, mechanical, electrical and metal industries were located in Barreiro. In 1960, 60.7\% of the municipality's active population was employed in the secondary sector, however in 2011 this figure had plummeted to 19.1\%. After 1991, at the peak of the employment crisis associated with deindustrialization, the city of Barreiro entered a serious demographic recession, having lost $21.7 \%$ of its population between this year and 2011 (a loss of 10,395 inhabitants).

Guimarães and Vizela are two neighbouring cities in the northwest of Portugal, in an area traditionally known for its dispersed settlement. The region in which these two cities are located is the quintessential territory of diffuse industrialization and urban sprawl. Its landscape boasts a blend of rural, forest, industrial and urban interpenetration. Guimarães is an old city with a historical centre of great heritage value, acknowledged by UNESCO, while Vizela is a younger and more atypical city, whose development has stemmed from the industrialization of small and medium-sized companies. Unlike Lisbon and Barreiro, which have been shrinking for decades, these cities only entered a demographic recession in the last intercensal period, resulting from a multi-causal process upon which urban dispersion, the economic crisis (less employment in the trade and construction industries), and societal changes (migration of the young population, postponement of marriage age, reduction in fertility) had a major effect: the city of Guimarães lost 


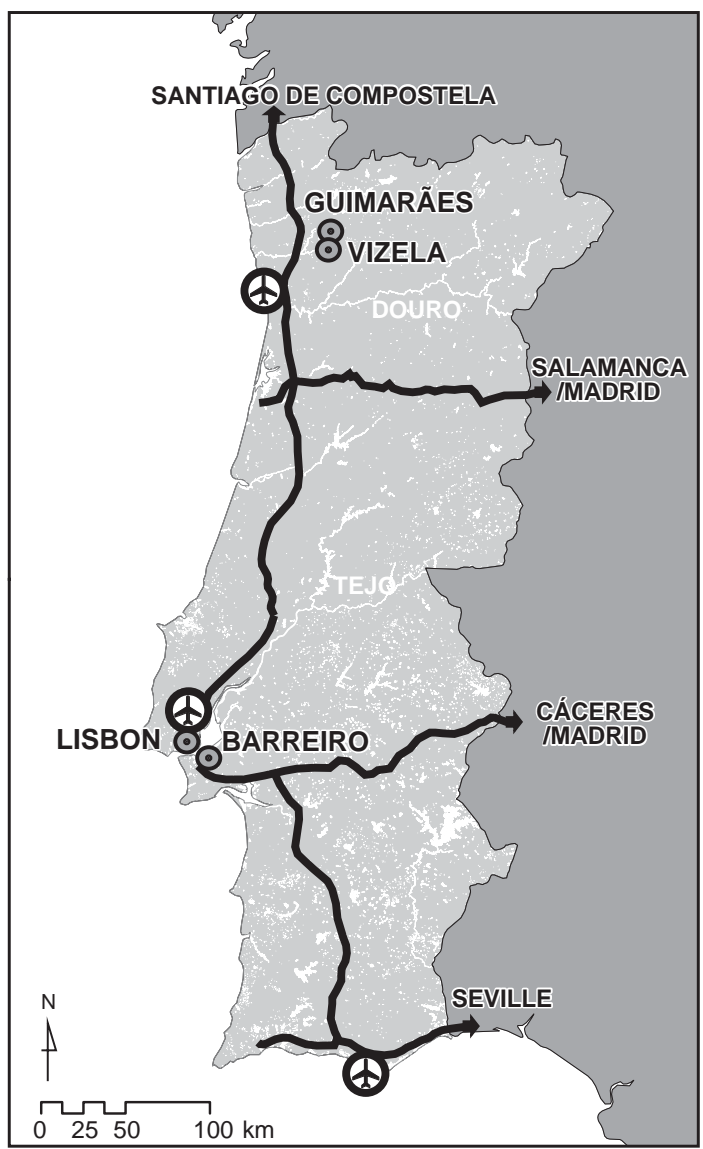

Figure 1. Cities under study

$8.8 \%$ of its inhabitants between 2001 and 2011 (around 4,600 people), and Vizela witnessed a $16.3 \%$ drop in its population (a loss of 2,065 inhabitants) despite its region having continued to report demographic growth.

\section{Findings analysis and discussion}

\section{Results of the ruin inventory: the extension of urban ruination}

Based on the aforementioned methodology, 2,834 ruined structures were identified. The ruins occupy a total extension of 121.9 ha in the set of four cities under study. This area increases to 194.8 ha if we include the non-constructed surface of the respective curtilages (Tab. 2). As may be noted, this corresponds to an average of one ruin for every two blocks, and to $1.6 \%$ of the total urban area of the four cities occupied by abandoned properties and those with derelict structures.

Our figures show that the ruins are not rare cases or uncommon occurrences in the landscape, but rather banal features of the cities under study. Notwithstanding, the situation varies from city to city. There are significant differences as far as the scope of ruination is concerned. In the cities of Barreiro and Lisbon, the ruins are more perceptible, occurring with higher density and occupying a more extensive area: while in Barreiro there 
Table 2. Presence and density of ruins in the four cities under study

\begin{tabular}{|c|c|c|c|c|c|c|c|}
\hline & \multicolumn{3}{|c|}{ Ruins } & \multirow{2}{*}{$\begin{array}{c}\text { Urban area } \\
\text { occupied } \\
\text { by ruins } \\
{[\%]}\end{array}$} & \multirow{2}{*}{$\begin{array}{c}\text { Urban area } \\
\text { occupied } \\
\text { by ruins and } \\
\text { respective } \\
\text { curtilages } \\
{[\%]}\end{array}$} & \multirow[b]{2}{*}{$\begin{array}{c}\text { Ruins } \\
\text { per block }\end{array}$} & \multirow[b]{2}{*}{$\begin{array}{l}\text { Ruins } \\
\text { per hectare } \\
(\times 10)\end{array}$} \\
\hline & no. & $\begin{array}{l}\text { area } \\
\text { [ha] }\end{array}$ & $\begin{array}{c}\text { area including } \\
\text { curtilages } \\
\text { [ha] }\end{array}$ & & & & \\
\hline Barreiro & 382 & 16.05 & 19.62 & 2.4 & 2.9 & 1.3 & 5.7 \\
\hline Guimarães & 210 & 13.99 & 25.13 & 0.6 & 1.1 & 0.3 & 0.9 \\
\hline Lisbon & 2,172 & 89.75 & 144.96 & 1.1 & 1.7 & 0.6 & 2.6 \\
\hline Vizela & 70 & 2.14 & 5.11 & 0.3 & 0.8 & 0.3 & 1.0 \\
\hline Total & 2,834 & 121.93 & 194.81 & 1.0 & 1.6 & 0.6 & 2.3 \\
\hline
\end{tabular}

Source: Own data obtained from aerial images

is, on average, more than one ruin per block, in Guimarães and Vizela a ruin appears in every three blocks. In Vizela, derelict areas occupy $0.75 \%$ of the city's surface and in Guimarães, approximately 1\%. In Lisbon, however, $1.7 \%$ of the city's area is covered by ruins and in Barreiro, this figure increases to almost $3 \%$. The magnitude, agedness and persistence of urban shrinkage appear to justify these differences, since a higher presence of ruins may be observed in the cities that have experienced demographic regression for longer and which have been subject to more severe shrinkage rates.

Several types of ruins coexist in the cities. Some derelict structures occupy a huge surface, although these are not the most predominant. Old factories and hangars of abandoned warehouses, disused railway lines and stations, old cinemas and closed down sports pavilions, old schools, military barracks and empty fire stations fall under this category. Several situations of this type may be observed in the four cities under study, particularly related to the debris of deindustrialization, which is particularly striking in Barreiro. Old, derelict rural houses, some of a noble size, belonging to former country estates that were swallowed by urban expansion, and old chalets and palaces, isolated by private walls, forming another genre of ruins are visible in the cities under study, above all in Lisbon, Guimarães and Vizela.
Generous sized plots are also associated with these properties, almost always with areas over $1,000 \mathrm{~m}^{2}$. However, the most frequent examples of ruins are the attached multiunit buildings, which are perfectly integrated in the urban fabric, composed, in some cases, of two or three-storied townhouses, in others, of apartment buildings. These structures tend to emerge somewhat randomly across the landscape, forming unexpected 'holes' or hollow spaces in the urban fabric.

As far as their location is concerned, the inventory shows that the ruins are quite scattered in the cities under study (Fig. 2 to Fig. 5). In fact, one cannot say that the ruins are confined to certain parts of the city, or that well defined ruination clusters may be pinpointed in the urban area. In Lisbon, ruination is expressed in the form of fine grain dust over the oldest central neighbourhoods surrounding Baixa (the centre, reconstructed after the earthquake of 1755). It may be said that the haze of ruins covers all the built environment, but diminishes as one moves away from the River Tagus and progresses towards the neighbourhoods constructed in the second half of the twentieth century, mainly designed for the middle classes. Larger ruins may be found beyond the borders of the city, to the north and north-east, and especially along the riverside, in the north-east sector, in a former specialized industrial area that depended on the port. 


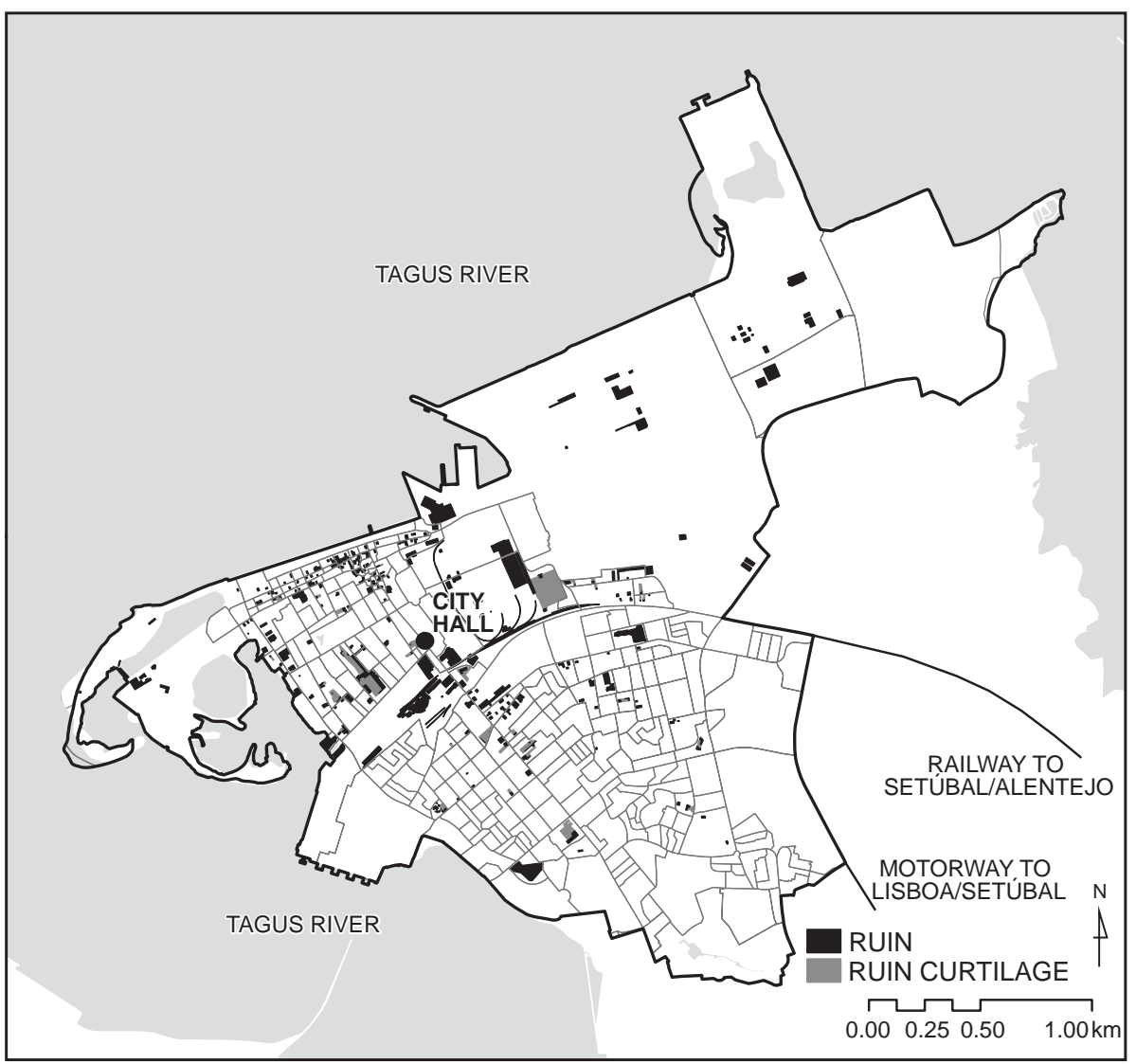

Figure 2. Ruins in the city of Barreiro

In Barreiro, the ruins are also quite scattered. A similar outline to that observed in Lisbon may be detected in this city. A more dense cloud of dust with finer grains, formed essentially by residential buildings integrated in small urban plots, may be observed in the oldest neighbourhoods, to the north, and in the traditional centre of the city. In this central area, a number of large derelict structures, connected to equipment buildings and abandoned transport infrastructures may also be found. To the south and south-east, where the new pluri-family high-rises built mainly after the 1970s are located, the ruins become rarer. However, in contrast with the powdered pattern of small ruination patches that may be observed in the denser construction area, a different ruination model may be found in the peripheral areas of the city, made up of larger and more individualized polygons. These polygons are large industrial buildings and derelict warehouses that have remained standing among huge empty plots discarded by recent demolition.

There is a lower density of ruins in Guimarães and Vizela. Ruination is more dispersed, and at first glance, more random. In Vizela, the ruins are thinly scattered across the urban area with no apparent order. In Guimarães, although widespread dispersion appears to be the norm, a slight tendency towards clusters of ruins may be perceived in the more compact built areas near the city centre, although in the medieval historical 


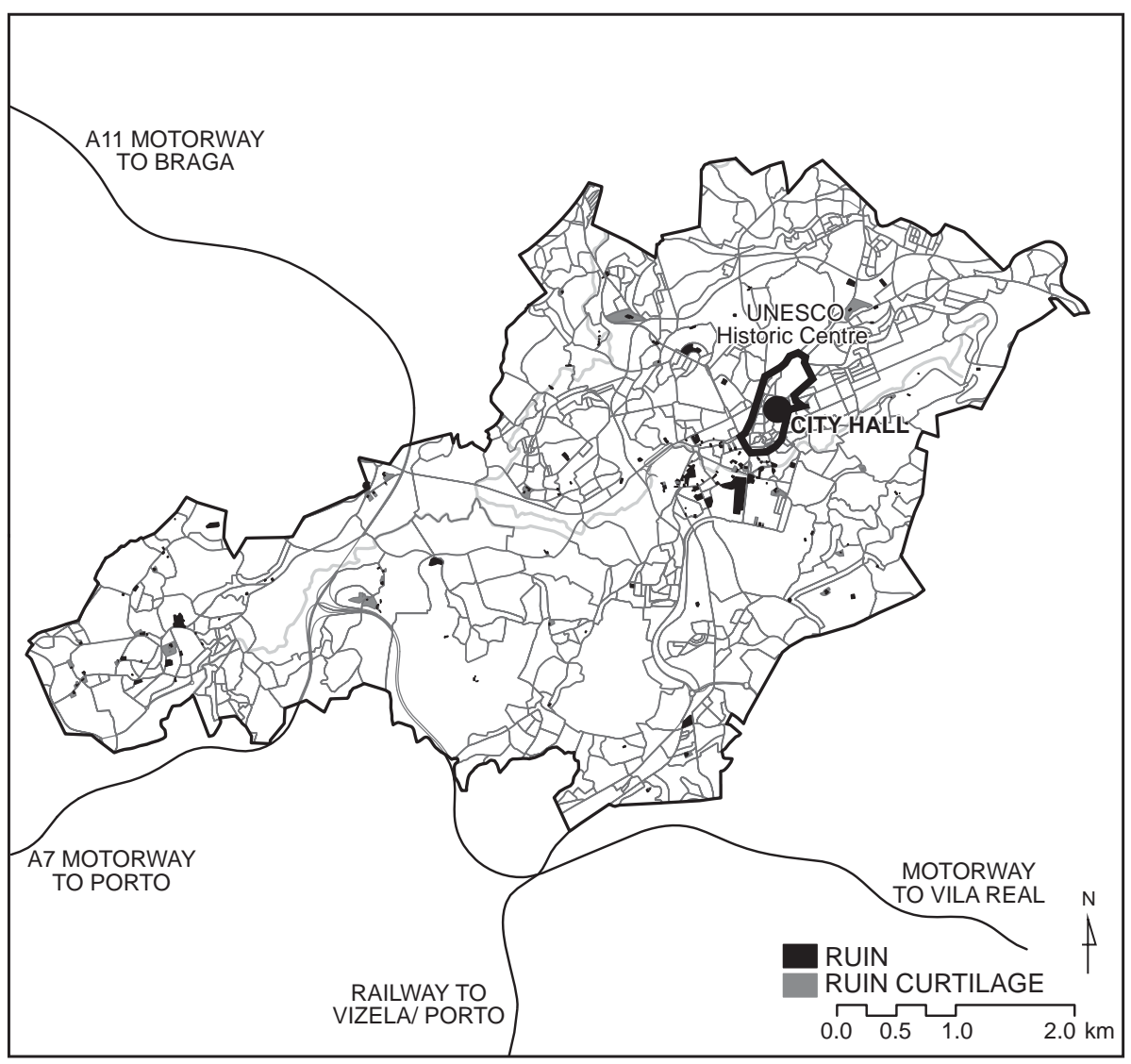

Figure 3. Ruins in the city of Guimarães

centre itself(designated a World Heritage Site by UNESCO) there are practically no ruins.

\section{Results of the multiple regression analysis}

As previously mentioned in the methodology section, a Multiple Linear Regression Analysis (MLR) was used as the technique to investigate the causes of urban ruination. This technique may be used with two purposes: as a predictive model, i.e. to predict the value a dependent variable will take on according to the variation of two or more predictors; or as an explanatory model, i.e. to determine the extent to which the variation of a dependent variable may be explained by a certain set of factors, and also the contribution of each factor to explaining the variance. In the present study, MLR was conducted for the latter purpose.

In order to test the suitability of the method, we began by ruling out the possibility of nonlinear relationships between the dependent variable and the predictors. The scatter plot analysis enabled us to check that there was no violation of the linearity assumption. However, it immediately became clear in this exploratory analysis that some of the independent variables did not appear to present an obvious relationship with ruin density. By using the Pearson correlation coefficients, this fact was confirmed (Tab. 3): no statistically significant correlations were found among 


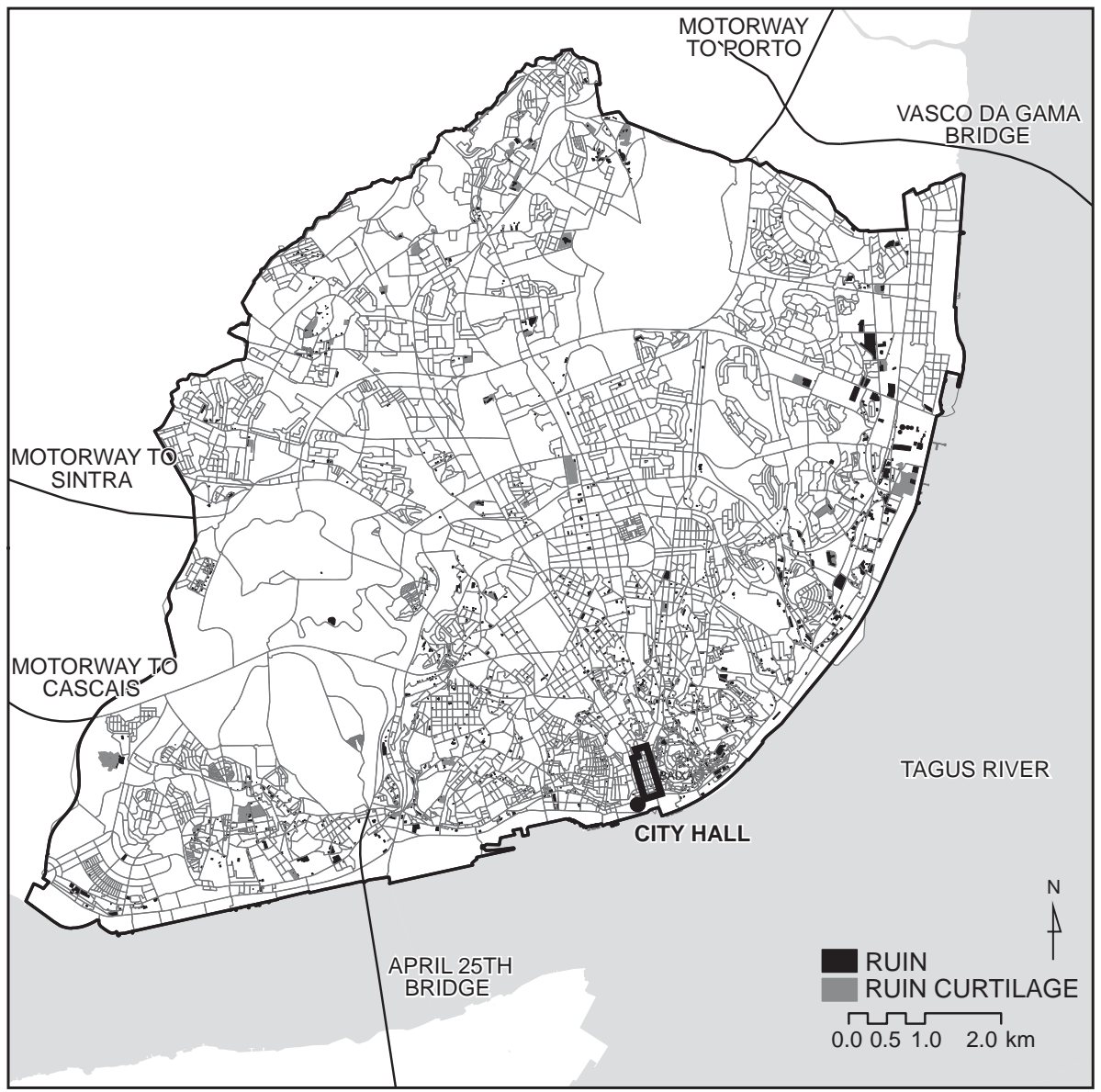

Figure 4. Ruins in the city of Lisbon

three independent variables, namely unemployment rate, proportion of residents with higher education, and public housing and ruin density. Moreover, a further four variables - population growth, variation of resident population employed in the secondary sector, proportion of income support recipients and percentage of foreign residents from non-European countries - were found to have low coefficients $r(< \pm 0.4)$, indicating a weak relationship with ruin density.

In this exploratory analysis phase, we immediately suspected that most of the independent variables we were testing did, in fact, have a limited explanatory power over the problem under debate, despite the theoretical arguments. The correlations suggested that the distribution of ruins in the four cities under study was far less dependent on the social structure, economic and employment variables than one might have thought, considering how these types of justifications are highlighted in the literature. This suspicion was confirmed when the MLR was run. Of the ten independent variables imported to the SPSS, only three were inserted in the model as predictors; the remaining seven were excluded by the programme due to the fact that they had no significant relationships, added no explanatory power, or were 


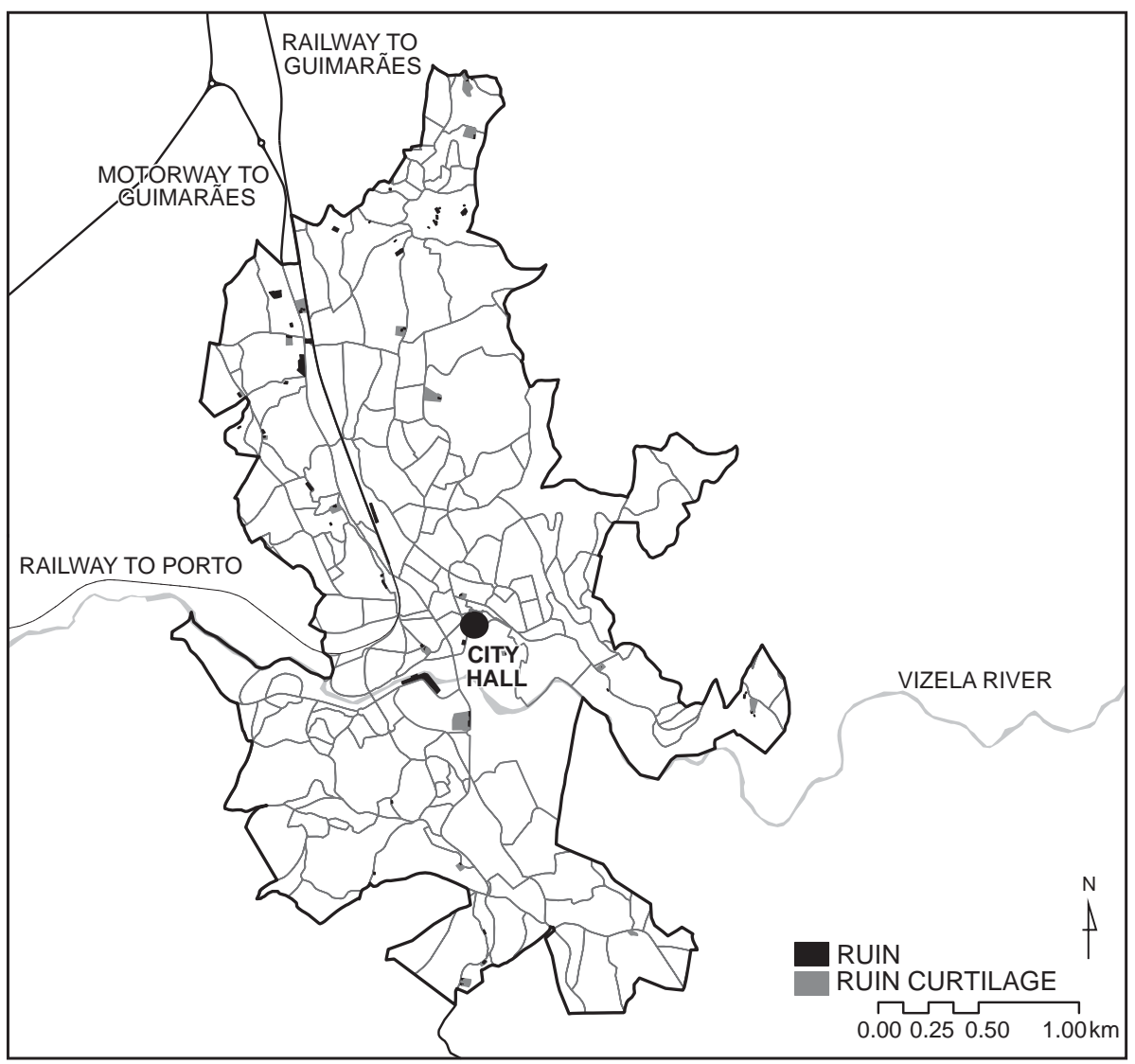

Figure 5. Ruins in the city of Vizela

Table 3. Relationship between independent variables and ruin density (measured by the Pearson correlation coefficient) in the cities under study

\begin{tabular}{|l|c|}
\hline \multicolumn{1}{|c|}{ Pearson correlation coefficient $(r)$} & Ruin density \\
\hline Population growth 2001-11 & $-0.303^{*}$ \\
Ageing index & $0.604^{*}$ \\
Variation of resident population employed in the secondary sector 2001-11 & $-0.303^{*}$ \\
Unemployment rate & 0.179 \\
Income support recipients & 0.374 * \\
Foreign residents from non-European countries & $0.372{ }^{\star}$ \\
Residents with higher education (over 25 years) & -0.150 \\
Residences in buildings constructed before 1946 & 0.559 * \\
Residences without bathroom facilities & $0.545^{*}$ \\
Public housing & 0.144 \\
\hline
\end{tabular}

* correlation is significant at the $99 \%$ confidence level (p-value $<0.01)$ 
redundant. Notwithstanding, these three predictors proved to be sufficient to explain $57.3 \%$ of the total variance of the ruins.

The results of the MLR are summarised in Tables 4 and 5. Insertion of the variables in the model was conducted according to the stepwise method, as already mentioned. The control parameters confirmed that the assumptions regarding multicollinearity had been respected (VIF $\approx 1$ and tolerance $>0.2$ in all the steps) and that the results of the model fulfilled the assumption of independent errors (confirmed by the Durbin-Watson statistic $=2.022)$ and the absence of influential values (Cook's Distance $\leq 0.511)$. Residual normality was confirmed graphically, and no indication contradicting the assumption of normality was found in the normal PP-plot of regression standardized residuals. Therefore, the results of the MLR may be considered valid, and the three factors adopted by the model may be accepted as those that best manage to explain ruination in the cities under study.

Given the MLR results, demographic ageing was observed to be the strongest explanation for ruination in the four cities that are the focus of this study. In fact, the ageing index was the first predictor to be inserted in the model. This variable alone proved to be sufficient to explain $35.7 \%$ of the ruins' total variance, thus it has a crucial responsibility in urban ruination. Of the three predictors that were inserted in the model, it is this one that best explains the differences in ruin density among the neighbourhoods of the cities under study.

The second most influential predictor was the percentage of residences with no bathroom facilities. This variable had been selected as an indicator of bad quality of the built environment. The aim was to use it to describe the more obsolete and deficiently equipped residences. The fact that it emerges as the second most important predictor means that

Table 4. Model summary of MLR (stepwise)

\begin{tabular}{|c|c|c|c|c|c|c|c|c|}
\hline \multirow{2}{*}{ Step } & \multirow{2}{*}{$R$} & $R^{2}$ & Adjusted $R^{2}$ & $F$ & Sig. & \multicolumn{2}{|c|}{$\begin{array}{c}\text { Durbin- } \\
\text { Watson }\end{array}$} & \multicolumn{2}{|c|}{ Cook's distance } \\
\cline { 5 - 8 } & & & & & & & min. & max. \\
\hline 1 & 0.604 & 0.365 & 0.357 & 44.225 & 0.000 & - & - & - \\
2 & 0.733 & 0.538 & 0.526 & 44.244 & 0.000 & - & - & - \\
3 & 0.767 & 0.589 & 0.573 & 35.820 & 0.000 & 2.022 & 0.000 & 0.511 \\
\hline
\end{tabular}

Table 5. Estimated model coefficients of MLR (stepwise)

\begin{tabular}{|c|c|c|c|c|c|c|c|c|}
\hline \multirow{2}{*}{\multicolumn{2}{|c|}{ Step }} & \multirow{2}{*}{ Beta } & \multirow{2}{*}{ Stand. Error } & \multirow{2}{*}{ Stand. Beta } & \multirow{2}{*}{ t. } & \multirow{2}{*}{ Sig. } & \multicolumn{2}{|c|}{ Collinearity statistics } \\
\hline & & & & & & & & \\
\hline 1 & ageing index & 0.586 & 0.880 & 0.604 & 6.650 & 0.000 & 1.000 & 1.000 \\
\hline \multirow[t]{2}{*}{2} & ageing index & 0.489 & 0.078 & 0.504 & 6.290 & 0.000 & 0.946 & 1.057 \\
\hline & $\begin{array}{l}\text { [\%] residences } \\
\text { without bath- } \\
\text { room facilities }\end{array}$ & 30.346 & 5.686 & 0.428 & 5.337 & 0.000 & 0.946 & 1.057 \\
\hline \multirow[t]{3}{*}{3} & ageing index & 0.481 & 0.074 & 0.496 & 6.506 & 0.000 & 0.944 & 1.059 \\
\hline & $\begin{array}{l}\text { [\%] residences } \\
\text { without bath- } \\
\text { room facilities }\end{array}$ & 26.302 & 5.559 & 0.371 & 4.731 & 0.000 & 0.892 & 1.121 \\
\hline & $\begin{array}{l}\text { [\%] income sup- } \\
\text { port recipients }\end{array}$ & 29.341 & 9.619 & 0.234 & 3.050 & 0.003 & 0.935 & 1.070 \\
\hline
\end{tabular}


the characteristics of the built space, namely the lack of comfort of some residences, also have a significant impact on abandonment and ruination. The insertion of this factor in the second step of the model gave rise to an increase in the adjusted $R^{2}$ from 0.357 to 0.526 .

The third factor identified by the MLR as being relevant for the explanation of ruination was the proportion of income support recipients. This suggests that the presence of ruins is more accentuated in neighbourhoods where there is a higher concentration of poorer populations. However, this predictor's insertion in the third step of the MLR brought only a minor addition to the explanatory power of the model (below 5\%). A comparison of the standardized Beta coefficients shows that the influence of this factor is slight in relation to the aforementioned: it has a little less than half of the weight of ageing in the prediction of ruin density, and two thirds of the influence of residences without bathroom facilities. Furthermore, the higher standard error associated with this factor suggests that its effect on the dependent variable is also a little more volatile or unpredictable, given the fact that it is subject to greater inter-sample variability.

\section{Discussion of results}

At first glance, the results obtained may appear to be somewhat disappointing, given that not all the variables presented significant relationships, and most of them were observed to have a low explanatory power over the problem under debate. However, this finding is in itself an important result. The fact that certain assumed relationships between the independent variables and ruin density were not confirmed leads one to question theoretical conjectures on the determinants of ruination, calling for a review of assumptions that are frequently taken for granted. In this sense, this study adds to the existing literature on urban vacancy and dereliction.

The first important aspect to highlight is the low relevance of the economic variables. Despite a broad and influential theory linking urban shrinkage to crisis, industrial restructuring and economic transformation, we found no proof that these are relevant and common causes of dereliction and ruination in the four cities under study. By using the proportion of the population with higher education, we set out to test the hypothesis advanced by Silverman et al. (2012) that the spaces better related to the knowledge economy's 'new urban regime' are less vulnerable to ruination; this was not confirmed. The decrease of the population with job in the secondary sector, used as a measure of deindustrialization, was not identified as a critical variable either. The determination of Pearson's $r$ made it possible to detect only a weak relationship between a decline in population with activity in the secondary sector and ruin density. It may be argued that had the percentage of the area of each statistical unit occupied by derelict properties been used, instead of the number of ruins per hectare, perhaps the results might have been more expressive, given that the industrial ruins occupy extensive areas. Notwithstanding, what the results clearly suggest is that the economic macro-explanations are unable to explain urban ruination, which seems to corroborate the Deng and Ma (2015)'s conclusions. As Haase et al. (2014: 1529) wisely assert, "economic decline in the course of a crisis of Atlantic Fordism might explain the emergence of population losses" and dereliction in a particular setting, "However, in other settings, it might not have enough explanatory power".

Finally, no relationship between derelict spaces and unemployment were observed, thus leading one to assume that the link between crisis and ruination is not as immediate or direct as the more economicist visions lead one to believe. There may be outbreaks of unemployment triggered by crises, however for this to be reflected in the landscape in the form of ruins, there would have to be a long-lasting depressed economic environment. Hence, it may well be that the 'peripheralization' concept - defined by Lang (2012) 
as a complex and multidimensional sociospatial process, both complementary to and in opposition of polarization, reflected in economic marginalization, loss of power and the worsening (objective and subjective) of isolation and remoteness - is more relevant to the debate on ruination than crisis.

The social variables that were observed to be relevant to the problem under debate are also worthy of mention. Contrary to what has been found in successive studies conducted in the USA, racialization does not appear to be related to the ruination of the cities in this study. Other studies had already considered the possibility of the ethnic issue not having so much importance in other countries as in the USA as a driver of land abandonment and dereliction (Hackworth 2016).

The hypothesis that the social housing sector is more efficient than the private sector with regard to maintaining housing stock, suggested by Couch and Cocks (2013), was not confirmed; neither, however, was the opposite. Hence, the type of property appears not to be a relevant variable for the issue at hand. Conversely, our research pointed to the characteristics of built environment, namely housing, being crucial to the explanation of urban ruination and abandonment. The decisions and actions of human actors are not taken in abstract isolation, detached from reality made up of the assemblage of material culture elements, technology and nature; on the contrary, they are formed and emerge as being embedded in and influenced by this network of actors and 'actants' in interaction (Latour 2005). In this respect, the data we analyzed show that it is not so much the agedness of buildings, but rather the poor quality of housing and the technical and functional obsolescence of the buildings that lead to abandonment and ruination, contrary to what other studies found (e.g. Silverman et al. 2012; Deng \& Ma 2015). This finding may be a sign that there is in this particular aspect a difference between North American cities and European cities. In fact, old buildings may be attractive to investors and residents due to their different atmosphere. In cities where urban rehabilitation is an adopted local strategy and there are effective heritage protection and conservation policies - such as in Guimarães, with its historic centre designated as a World Heritage Site by UNESCO - the historical centres in which older buildings are concentrated may be quite resistant to ruination.

\section{Conclusion}

Urban geography has quite seriously neglected ruination and ruins, especially ruins from the recent past, and few specific studies have focused on these features. However, our inventory of the ruins of the four cities under study in this article shows that derelict buildings and structures are neither rare nor exceptional in the contemporary urban landscape. In fact, they are somewhat banal, at least in shrinking cities, as are the cases analyzed herein. In addition to being frequent, the ruins are scattered across the urban fabric with no apparent order. Considering the diffusion of ruins on the maps, it may be said that ruination can suddenly arise in any location. In a more detailed comparison of the four cities, one may observe that whenever urban shrinkage is older and persistent, the ruins appear to be more frequent and visible in the landscape.

The main aim of this article was to discuss the reasons behind urban ruination. It set out, above all, to investigate the possible contributory and causative structural factors of ruination. In the case of the four Portuguese cities under study, the demographic factors are the most relevant, namely ageing. The ageing population variable was found to best explain the variance of the ruins. Hence, the findings support the argument that highlights demographic ageing as the main cause of urban shrinkage (Rieniets 2009) and, consequently, of the abandonment and ruination of the built environment. Notwithstanding, the secondary and supporting contribution of urban sprawl may also be reflected in this data, given that ageing may be intensified at a local level by the departure of young couples. If we 
assume that population ageing is a structural tendency in societies of the Global North, and one that is highly unlikely to invert in the near future (Lesthaeghe 2014), important conclusions may be drawn from this data as far as the future of cities and the challenges that will present themselves in the near future to the management of the built environment are concerned. The trend is most likely to sway towards fewer plans for construction and more plans for renovation, adaptation and reuse, or simply for demolition.

This study also highlighted the relevance of the materiality of the built environment in ruination. After demographic ageing, the variable revealing the ruins' highest predictive power was the incidence of residences without bathroom facilities. This variable describes the technical and functional obsolescence of the ruins and refers to the infrastructural conditions of the buildings, standards of comfort and housing conditions. It may be concluded that the physical conditions of the properties are also deemed a cause of abandonment and ruination. This is an important conclusion, as it sheds light upon the issue from a 'more-than-human' perspective, highlighting the 'force of things' and the interconnectedness of humans with nonhumanity in the explanation of social phenomena, in line with the arguments of authors such as Latour (2005) and Bennett (2004).

The present study has underlined the notion that ruination is not detached from socio-spatial marginalization processes. Populations with fewer resources are less capable of investing in the maintenance of the built environment, and neighbourhoods in which there is a prevalence of economically vulnerable and socially excluded social groups are less attractive for investment. In conjunction, these two factors contribute to a more facile formation of ruins and a tendency for them to remain in the landscape over a long period of time.

On a final note, the highly contingent nature of this issue cannot be underestimated. The research conducted for this study has shed light upon a crucial finding, namely that structural causes and macro-explanations alone are insufficient to explain urban ruination. Randomness and unpredictability are also intrinsic to the phenomenon under study, as pointed to in other studies (Deng \& Ma 2015; Brito-Henriques 2017), which may be a consequence of fortuitous events, specific stories about certain places or buildings, micro-local reasons associated with the precise location of the properties and their surrounding neighbourhoods. More 'sensitive to specifics' research with studies that "shift away from the pattern-orientated research towards a more process-orientated, contextsensitive research" (Haase et al. 2016: 98-99) are sorely needed so that this contingent dimension of ruination may be explored.

\section{Acknowledgements}

This research was supported by Portuguese national funds through the Fundação para a Ciência e a Tecnologia (FCT), I.P. under the project grant PTDC/ATP-EUR/1180/2014.

\section{Editors' note:}

Unless otherwise stated, the sources of tables and figures are the authors', on the basis of their own research.

\section{References}

Accordino J., Johnson G.T., 2000. Addressing the vacant and abandoned property problem. Journal of Urban Affairs, vol. 22, no. 3, pp. 301-315.

Apel D., 2015. Beautiful terrible ruins: Detroit and the anxiety of decline. New Brunswick, NJ and London: Rutgers University Press.

AUDIRAC I., 2009. Urban shrinkage amid fast metropolitan growth (two faces of contemporary 
urbanism) [in:] K. Pallagst et al. (eds.), The future of shrinking cities: Problems, patterns and strategies of urban transformation in a global context, Berkeley, CA: Center for Global Metropolitan Studies, pp. 69-90.

BeAUREgARD R., 2012. Voices of decline: The postwar fate of U.S. cities. New York: Routledge.

Bluestone B., Harrisson B., 1982. The deindustrialization of America: Plant closures, community abandonment, and the dismantling of basic industry. New York: Basic Books.

Bontje M., Musterd S., 2012. Understanding shrinkage in European regions. Built Environment, vol. 38, no. 2, pp. 153-161.

BRITO-HenRIQUES E., 2017. Arruinamento e regeneração do espaço edificado na metrópole do século XXI: o caso de Lisboa. EURE - Revista Latinoamericana de Estudios Urbano Regionales, vol. 43, no. 128, pp. 251-272.

Brito-Henriques E., Morgado P., Cruz D., 2018. Morfologia da cidade perfurada: padrões espaciais de ruínas e terrenos vacantes em cidades portuguesas. Finisterra - Revista Portuguesa de Geografia, vol. 53, no. 108, pp. 111-133.

BuRguess E.W., 1929. The growth of the city. An introduction to a research project [in:] R.E. Park, E.W. Burguess, R.D. McKenzie (eds.), The city, Chicago, IL: The University of Chicago Press, pp. 47-62.

Coole D., Frost S., 2010. Introducing the New Materialisms [in:] D. Coole, S. Frost (eds.), New Materialisms. Ontology, agency, and politics, Durham, NC and London: Duke University Press, pp. 1-23.

Couch C., Cocks M., 2013. Housing vacancy and the shrinking city: Trends and policies in the UK and the city of Liverpool. Housing Studies, vol. 28, no. 3, pp. 499-519.

Couch C., Leontidou L., Arnstberg K.-O., 2007. Introduction: definitions, theories and methods of comparative analysis [in:] C. Couch, L. Leontidou, G. Petschel-Held (eds.), Urban sprawl in Europe: Landscapes, land-use change and policy, Oxford and Malden, MA: Blackwell, pp. 3-38.

Deng C., MA J., 2015. Viewing urban decay from the sky: A multi-scale analysis of residential vacancy in a shrinking U.S. city. Landscape and Urban Planning, vol. 141 (September), pp. 88-99.
DeSilvey C., Edensor T., 2013. Reckoning with ruins. Progress in Human Geography, vol. 37, no. 4, pp. 465-485.

Edensor T., 2005. Industrial ruins: Spaces, aesthetics and materiality. New York: Berg.

Florentin D., Fol S., Roth H., 2009. La "Stadtschrumpfung" ou "rétrécissement urbain" en Allemagne: un champ de recherche émergent. Cybergeo: European Journal of Geography.

FREY W.H., 2005. Metro America in the new century: Metropolitan and central city demographic shift since 2000. Washington, DC: The Brookings Institution.

González-Ruibal A., 2008. Time to destroy: An archaeology of supermodernity. Current Anthropology, vol. 49, no. 2, pp. 247-279.

Haase A., Rink D., Grossmann K., Bernt M., MykHnenko V., 2014. Conceptualizing urban shrinkage. Environment and Planning A, vol. 46, no. 7, pp. 1519-1534.

HACKWORTH J., 2016. Why there is no Detroit in Canada. Urban Geography, vol. 37, no. 2, pp. 272-295.

Hollander J., 2010. Can a city successfully shrink? Evidence from survey data on neighborhood quality. Urban Affairs Review, vol. 47, no. 1, pp. 129-141.

Hollander J., 2011. Sunburnt cities: The Great Recession, depopulation, and urban planning in the American Sunbelt. London and New York: Routledge.

Hort H., 1939. The structure and growth of residential neighborhoods in American cities. Washington, DC: Federal Housing Administration.

Hospers G.-J., 2014. Policy responses to urban shrinkage: From growth thinking to civic engagement. European Planning Studies, vol. 22, no. 7, pp. 1507-1523.

KeLLING G.L., WILSON J.Q., 1982. Broken windows: The police and neighborhood safety. Atlantic Monthly, vol. 249, no. 3, pp. 29-38.

Kitchin R., O'Callaghan C., Gleeson J., 2014. The new ruins of Ireland? Unfinished estates in the post-Celtic Tiger era. International Journal of Urban and Regional Research, vol. 38, no. 3, pp. 1069-1080. 
MAH A., 2012. Industrial ruination, community, and place: Landscapes and legacies of urban decline. Toronto and London: University of Toronto Press.

MARTIN D., 2014. Introduction: Towards a political understanding of new ruins. International Journal of Urban and Regional Research, vol. 38, no. 3, pp. 1037-1046.

Martinez-Fernandez C., Audirac I., Fol S., CunNINGHAM-SABOT E., 2012. Shrinking cities: Urban challenges of globalization. International Journal of Urban and Regional Research, vol. 36, no. 2, pp. 213-225.

Newman G.D., Bowman A.O'M., Lee R.J., Kim B., 2016. A current inventory of vacant urban land in America. Journal of Urban Design, vol. 21, no. 3, pp. 302-319.

Newman G., KIM B., 2017. Urban shrapnel: Spatial distribution of non-productive space. Landscape Research, vol. 42, no. 7, pp. 699-715.

Newman G., Park Y., Bowman A.O'M., Lee R.J., 2018. Vacant urban areas: Causes and interconnected factors. Cities, vol. 72, pp. 421-429.

Oswalt P., Rieniets T. (eds.), 2006. Atlas of shrinking cities. Ostfildern: Hatje Cantz Verlag.

Pagano M.A., Bowman A.O.M., 2000. Vacant land in cities: An urban resource. Brookings Center on Urban \& Metropolitan Policy Survey Series, Washington, DC: The Brookings Institution, https://www.brookings.edu/research/ vacant-land-in-cities-an-urban-resource/ [20 March 2017].

PÁLSSON G., 2012. These are not old ruins: A heritage of the Hrun. International Journal of Historical Archaeology, vol. 16, no. 3, pp. 559-576.
PétursdótTIR P., 2013. Concrete matters: Ruins of modernity and the things called heritage. Journal of Social Archaeology, vol. 13, no. 1, pp. 31-53.

Rieniets T., 2009. Shrinking cities: Causes and effects of urban population losses in the twentieth century. Nature and Culture, vol. 4, no. 3, pp. 231-254.

SCHLAPPA H., 2016. If not growth what then? Rethinking the strategy process for shrinking cities [in:] W.J.V. Neill, H. Schlappa (eds.), Future directions for the European shrinking city, New York and London: Routledge, pp. 180-191.

Silverman R.M., Yin L., Patterson K.L., 2012. Dawn of the dead city: An exploratory analysis of vacant addresses in Buffalo, NY 20082010. Journal of Urban Affairs, vol. 35, no. 2, pp. 131-152.

WieCHMANn T., 2008. Errors expected - Aligning urban strategy with demographic uncertainty in shrinking cities. International Planning Studies, vol. 13, no. 4, pp. 431-446.

Wiechmann T., Pallagst K., 2012. Urban shrinkage in Germany and the USA: A comparision of transformation patterns and local strategies. International Journal of Urban and Regional Research, vol. 36, no. 2, pp. 261-280.

WOODWARD C., 2012. Learning from Detroit or 'the wrong kind of ruins' [in:] A. Jorgensen, R. Keenan (eds.), Urban wildscapes, London and New York: Routledge, pp. 17-32. 